\title{
The Financial Crisis in the European Union:Legal and Economic Aspects of an Anti-democratic Stabilization Mechanism
}

\author{
Dr. Nellie Munin, Adv. \\ Senior Lecturer, the law school \\ Zefat Academic College \\ Zefat, Israel \\ gmun@netvision.net.il
}

\begin{abstract}
This article presents the dilemmas encountered by European Union (hereby - EU) leaders facing an ongoing severe financial crisis, as the mechanism developed by them to pull out of the crisis is criticized for being anti-democratic, both in legal and in economic terms.
\end{abstract}

\section{Keywords-the european union; financial crisis; democracy.}

\section{INTRODUCTION}

In recent years the EU is experiencing a severe financial crisis. This crisis particularly hit some of its most vulnerable economies such as Greece, Portugal, Italy, Spain and Ireland. Some of these countries turned to the EU for financial assistance, but the crisis caught the EU unprepared, without due mechanisms to supply the necessary help. At first, temporary new mechanisms were established: the EFSM (European Financial Stability Mechanism) and the EFSF (European Financial Stability Facility) [1]. They were later replaced by a permanent mechanism: ESM (European Stability Mechanism)[2]. Financial assistance is basically obtained from three optional resources: EU resources, individual EU Member States and international organizations: the IMF and the World Bank. Due to the sense of urgency, these mechanisms were quickly established by conclusion of international agreements between the Eurozone countries, complemented by a pack of EU legislation, known as the 'six pack' [3]. There was no much time for public discourse. However, as the time passes public and professional discourse intensifies regarding the question: were the steps taken democratic? Could more democratic instruments have been developed to achieve the same purpose? [4]

\section{THE 'DEMOCRATIC DEFICIT'}

The discourse regarding the financial instruments developed by the EU to pull out of the financial crisis builds upon a broader EU discourse, regarding the 'democratic deficit' characterizing the entire EU regime [5]. Since the EU is not a state, neither a federation, but rather a dynamic alliance heading towards a full economic and monetary union, its regime is characterized by an ongoing process of powers' delegation from national sovereigns to supranational institutions. Due to this process, the EU regime gradually deviates from the traditional perception of majoritarian democracy. This 'democratic deficit' is believed to be reflected, among other things, by five major elements [6]:

- Increase in executive power (i.e. EU institutions, particularly EU Commission) and decrease in national parliamentary control.

- Relative weakness of the European Parliament, despite gradual increase of its powers by successive reforms of EU Treaties.

- No 'European' elections: although European citizens elect EU Parliament's members and their governments who sit in the Council and nominate EU Commissionaires, elections are not about the personalities and parties at the European level or the direction of the EU policy agenda.

- The EU agenda is too distant from the voters. According to commentators, this problem would not have been solved even if the two former problems would have been solved.

- European integration produces 'policy drift' from voters' ideal policy preferences, enabling governments to undertake policies at the European level that they cannot pursue at the domestic level, where they are constrained by parliaments, courts and corporatist interest group structures. In this context, the monetarist framework for the European Monetary Union is particularly mentioned.

The 'democratic deficit' thus refers mainly to the ability of EU citizens to affect the decision-making processes in the EU. However, while this discourse mainly concentrates on legal aspects of influence, later the economic aspects of 'democratic deficit' embodied in the EU's financial mechanism will also be addressed.

\section{LEGAL ASPECTS OF THE 'DEMOCRATIC DEFICIT'}

\section{A. Decision Makers in the Establishment Process}

The establishment of the mechanism devised by the EU to pull out of the financial crisis was mainly led by EU heads of 
states as well as by the Council of finance ministers. EU Parliament, which is perceived as the EU institution representing EU citizens in the best way, had only a limited role in the process. The EU Commission, which is an executive power without decision authority, had a strong indirect effect on the decision-making process, due to its professional power and the fact that it drafts most decisions and legislation at EU level. In this sense, it is argued that the decision-making process reflects, to a great extent, the 'democratic deficit' which is typical to EU functioning in general. Further claims refer to the low level of transparency of decision-making processes.[7]

On the other hand, it may be argued that heads of states and finance ministers of the countries involved are accountable to national parliaments and voters.

In the European Central Bank (ECB), responsible for EU monetary policy, the Governing Council is comprised of the governors of the national central banks of Eurozone Member States. The decision-making process at the ECB is often criticized for lack of sufficient transparency. However it should be remembered that neither the ECB nor the national central banks are 'democratic' institutions, but rather highly professional institutions, dealing with considerations which are beyond the understanding of most citizens.

\section{B. Decision Makers in the ESM}

The ESM is comprised of three levels of decision-making:

- A Board of Governors - comprised of finance ministers of the member states.

- A Board of Directors - composed of professional directors, each appointed by a Governor (and may be replaced for unsatisfactory functioning).

- A Managing Director - a professional responsible for the daily management of this mechanism.

While the two lower levels of decision making are professional, the highest level is political, thus being accountable to national parliaments and voters. The two Boards are entitled to consult with different stake-holders in the process of decision-making (although this authority is characterized for being totally subject to their discretion).

In the Board of Governors, decision making is subject to mutual agreement or to a qualified majority of $80 \%$ in decisive cases, while in other cases a quorum of $2 / 3$ of the voting rights will do. At least theoretically, this provision prevents the enforcement of any decision by a minority of members (although it may not prevent voting biased due to power relations between the member states).

The Board of Directors takes decisions by qualified majority, unless otherwise stated by the Treaty, a less flexible decision-making procedure compared to that of the Board of Governors, necessitating broad agreement at all times. This broad agreement is a 'democratic' element, meant to prevent a pragmatic minority veto, but may not prevent voting biased due to power relations between the member states.

This decision-making process may be criticized on grounds of full discretion and a lack of transparency and accountability obligations. At the same time, it should be weighed against the necessity for quick, efficient and professional emergency solutions when a crisis hits.

\section{The Assisted Country and the ESM}

Assistance through this mechanism is subject to a request by the country in need for it. This condition is criticized on grounds that there is no way to force a process of recovery on a Member if it does not request assistance. On the other hand, taking into account the heavy commitments and responsibilities imposed on a country in need for help by subjecting itself to this mechanism, it seems fair (and more democratic) to allow such a country to opt for another, more convenient solution if feasible.

All members of this mechanism are obliged to contribute to the financial pool established by it. A member that fails to respect its obligations in relation to paid-in shares or calls of capital or in relation to the reimbursement of the financial assistance may be deprived of its voting rights. This deterring sanction may have severe implications for the signatories heavily suffering from the crisis, who signed the Treaty to get financial aid but may find themselves deprived of their right to affect decision-making processes regarding this mechanism, if financial shortages escalate. Nevertheless, they agreed to this sanction by concluding the treaty. Furthermore, the deterring effect may be used as leverage by domestic decision-makers, to encourage the adoption of more cautious economic and financial policies, inevitable for a country's financial recovery, despite pressures assumed by domestic interest-groups.

\section{Coordination of Financial Policies}

The new mechanism provides for an ongoing surveillance of domestic budgets' drafts by the EU authorities, before they are confirmed by national parliaments, to ensure that the agreed budgetary constraints are met.

Naturally, any obligation to coordinate economic policies, as provided for by the Treaties, potentially derogates from the independent discretion of decision-makers democratically elected in each Eurozone member. At the same time, coordination of policies has been underlying the EU practice since its establishment and is inevitable for the achievement of economic and monetary integration. Formally, being provided for by a ratified international treaty it underwent a democratic approval procedure in the countries involved. In addition, it should not be forgotten that deviation of many EU Members from stability criteria, imposed by EU Treaties to prevent financial instability as well as its spillover, was one of the factors that facilitated the severe consequences of the current crisis. It was therefore imperative to ensure that such practices will be prevented in the future.

\section{E. Intervention of the European Court of Justice}

The European Court of Justice is the highest interpreter of EU law. Nevertheless, the international treaties establishing the financial mechanism were formally concluded outside the framework of EU law and thus the legitimacy of ECJ's intervention in their interpretation was doubted by some. However, in fact the subscribers of the Treaties are EU 
Member States. The governance is in the hands of the ministries of finance of these Members. The purpose is to give aid to Eurozone Member States. Thus, at least informally it may be perceived as part of EU law. It should be further noted that (probably due to this doubt) ECJ's involvement according to the treaties is limited only to specific circumstances. This limitation seems to balance between the interest for a democratic mechanism and the necessity to solve severe cases of non-compliance or disagreement.

It should be further mentioned, that even in democratic states, courts are inherently non-majoritarian but nevertheless are inevitable to ensure compliance with the law democratically established [8].

\section{F. $\quad$ Strong and Weak Countries}

As rich EU Members help less economically-stable Members to pull out of the crisis, it is argued that this help may have democratic short and long term implications. In the short term, this fact may imply total pragmatic domination of strong countries like Germany over the decision-making process, while the weaker countries are dragged into it without pragmatic influence. In the long run, this reality may change the current delicate balance of powers between EU (or Eurozone) Members, by gradually increasing the dependence of certain countries in others, thus potentially exposing the former to undesirable political pressures assumed by the latter, to change their positions regarding other aspects of the EU (or the Eurozone), in consideration for the financial support offered to them.

\section{G. International Organizations' Assistance}

While any step taken at EU level involves EU decision makers only, whether democratically elected or not, assistance offered by international organizations such as the World Bank and the IMF is subject to an international process of decisionmaking, where the Eurozone (or even EU) countries form a small part of the 188 Members, in terms of voting power. In these organizations, the EU is capable of assuming its influence informally, behind the scene, since it is one of their more generous contributors. However, other powerful contributors such as the US may counter-balance this informal effect. One way or another, this process is obviously remote from EU citizens in terms of their power to affect it directly or even indirectly. Having said that, it should be mentioned that participation in these organizations is also a result of concluding international treaties ratified domestically, that may be withdrawn at any time. In addition, assistance by these organizations is optional.

Interestingly, in some cases, the standards dictated by these organizations may serve transparency and accountability of decision-making bodies at EU level. Thus, for example, due to IMF standards, involvement of the private sector in decisionmaking processes was enabled by the ESM Treaty in certain circumstances.

\section{ECONOMIC ASPECTS OF THE 'DEMOCRATIC DEFICIT'}

While the financial crisis experienced by some EU Members seems, at first sight, to be totally subject to their responsibility, whether due to their deviation from stability criteria determined by EU treaties in terms of debts and deficits, or due to any other irresponsible economic or political behavior, there are voices in the EU pointing towards the rich and strong EU Members as being at least partly responsible for these consequences. It is mentioned that among the first countries which violated the financial stability criteria back in the early 2000s were France and Germany; that countries severely affected by the crisis such as Spain and Ireland had very small public deficits and debts before the crisis, but being part of the EU/Eurozone they suffer from the lack of sufficient governance instruments to react to the crisis. In this context insufficient labor mobility, stemming from the fact that this issue is still not completely centrally governed in the EU is mentioned [9], as well as the inability to opt for a moderate rate of inflation, to encourage market activity, due to the tough EU financial stability requirements [10]. It is further mentioned that German and Dutch banks, which acted as mediators between the rest of the world (where they could borrow money) and the weak Eurozone countries (to which they landed) exposed themselves to excessive risks and were not duly restrained by domestic regulators [11].

If this is true, the financial crisis may be viewed as a distributive conflict among Eurozone countries, necessitating not only the adjustment of the countries strongly affected by it but also of the strong EU Members such as Germany, to prevent factors such as loose lending standards in the rich countries, price divergence and gaps in unit labor costs from encouraging the current crisis or contributing to future crises.

If this is the case, the alleged 'democratic deficit' discussed in the former section may be decisive, because those who dominate of the decision-making process will determine, in fact, the definition of the crisis, its causes and the manner of its treatment. They will determine to what extent strong countries like Germany should be held at least partly accountable to the crisis and thus should be required to adjust their markets to the new reality. By determining the mechanism to pull out of the crisis, those who dominate the decision-making process determine to what extent the economically weaker countries would have the democratic instruments to impose this requirement on the strong countries, despite the financial assistance on which they depend. The definition of the crisis as a debt crisis or alternatively, as a crisis caused by banking and intra-Eurozone imbalances affects the optional solutions chosen: austerity in the severely affected countries in the former case, or adjustments in all EU countries to close gaps in fields such as prices and lending policies, in the latter case [12].

Up to this point, judging upon the instruments chosen in the EU/Eurozone to pull out of the crisis it seems that the financially strong countries succeed to impose their terms, opting for austerity in the severely affected countries, while avoiding deep overall adjustments. However, in the long term the current steps may not do, and the weak countries may discover their collective power and use it in EU/Eurozone institutions, where decision making is based, one way or another, on majority voting (similarly to the process that took place at the WTO). 


\section{CONClUSIONS}

The debate on the democratic and anti democratic aspects of the new financial regime in the Eurozone does not seem to come to any definite conclusion. Formal and informal, legal and economic considerations are used by different commentators to establish different conclusions. These conclusions are underlined by different political views as to the future of the Eurozone and maybe of the EU as a whole.

It is interesting to note, though, that while this debate continues, in practice the mechanisms to pull out of the crisis chosen by the Eurozone Members enhance the economic and financial integration between them, rather than opting out of this alliance. This choice may reflect the realization of both strong and weak Members that despite the possible disadvantages, this alliance is still advantageous enough for them. [13]

\section{REFERENCES}

[1] European Commission, 2013. 'About EFSF', available at http://www.efsf.europa.eu/about/index.htm; 'European Financial Stability Facility'. Available at http://ec.europa.eu/economy_finance/european_stabilisation_actions/efsf /index_en.htm; 'European Financial Stabilization Mechanism (EFSM)'. Available

http://ec.europa.eu/economy_finance/eu_borrower/efsm/index_en.htm; 'Financial Assistance in EU Member States.' Available at http://ec.europa.eu/economy_finance/assistance_eu_ms/index_en.ht

[2] Treaty Establishing the European Stability Mechanism (ESM), 2013. Available at http://www.european-council.europa.eu/media/582311/05tesm2.en12.pdf; Treaty on Stability, Coordination and Governance in the Economic and Monetary Union (TSCG), 2013. Available at http://european-council.europa.eu/media/639235/st00tscg26_en12.pdf

[3] Council Regulation (EU) No 1177/2011 of 8 November 2011 amending Regulation (EC) No $1467 / 97$ on speeding up and clarifying the implementation of the excessive deficit procedure, OJ L 306, 33; Council Directive 2011/85/EU of 8 November 2011 on requirements for budgetary frameworks of the Member States, OJ L 306, 41; Regulation (EU) No 1173/2011 of the European Parliament and of the Council of 16
November 2011 on the effective enforcement of budgetary surveillance in the euro area, OJ L 306, 1; Regulation (EU) No 1174/2011 of the European Parliament and of the Council of 16 November 2011 on enforcement measures to correct excessive macroeconomic imbalances in the euro area, OJ L 306, 8; Regulation (EU) No 1175/2011 of the European Parliament and of the Council of 16 November 2011 amending Council Regulation (EC) No 1466/97 on the strengthening of the surveillance of budgetary positions and the surveillance and coordination of economic policies, OJ L 306, 12; Regulation (EU) No 1176/2011 of the European Parliament and of the Council of 16 November 2011 on the prevention and correction of macroeconomic imbalances, OJ L 306, 25.

[4] J. Habermass, 'Democracy is at Stake'. Le Mond, November 27, 2011. Available at http://www.presseurop.eu/en/content/article/1106741juergen-habermas-democracy-stake.

[5] J.H.H Weiler, U.R. Haltern, and F. Mayer, (1995) 'European Democracy and its Critique', West European Politics, Vol. 18, No. 3, pp. 4-39.

[6] A. Follesdal and S. Hix, 'Why there is a Democratic Deficit in the EU: a Response to Majone and Moravcsik', Journal of Common Market Studies Vol. 44(3), pp. 533-562, 2006.

[7] M. Maduro, B. De Witte, and M. Kumm, M. 'The Democratic Governance of the Euro', Policy Paper 2012/08, (Florence: RSCAS). Available at http://cadmus.eui.eu/bitstream/handle/1814/23981/RSCAS_PP_2012_08 .pdf?sequence $=1$

[8] G. Majone. 'Europe's 'Democratic Deficit': The Question of Standards.' European Law Journal, Vol. 4, No. 1, pp. 5-28, 1998.

[9] L'Express Paris, Interview: 'Paul Krugmann: the Euro is a Shaky Construction', 6 September 2012, available at http://www.presseurop.eu/en/content/article/2648061-paul-krugmaneuro-shaky-construction

[10] K. Rogoff, 'Europe's Lost Keynesians, Project Syndicate, 23 May 2013, available at http://www.project-syndicate.org/commentary/a-structuralfocus-for-the-euro-crisis-by-kenneth-rogoff

[11] B. Eichengreen, 'Imbalances in the Euro Area', Berkeley, California (2010), available http://emlab.berkeley.edu/ eichengr/Imbalances_Euro_Area_5-2311.pdf

[12] P. Krugman, "End This Depression Now", W.W. Norton and Company (2012).

[13] B. Eichengreen, 'The Crisis of the Euro', Berkeley, California (n.d.), available at http://emlab.berkeley.edu/ eichengr/crisis_euro_projsyn.pdf. 